\title{
Importance of Genetic Factors in Male Fertility Disorders, Clinical Relevance of Epigenetic Markers in Male Infertility
}

\author{
DRAGOS BOTEZATU1,2\#, CRISTINA POPESCU ${ }^{3}$, ANDREI-DAN KORODI ${ }^{4}$, CRISTIAN FURAU $^{5}$, GHEORGHE FURAU 5 , \\ BOGDAN SOCEA $6,7 * \#$, CRANGU IONESCU6,7\#, MIHAI DIMITRIU6,7\#, DIANA CLAUDIA GHEORGHIU7,8\#, \\ NICOLAE GHEORGHIU7,8\#, IOIART IOAN ${ }^{1 \#}$ \\ ${ }^{1}$ Vasile Goldis Western University of Arad, Faculty of Medicine, Department of Urology, 86 Liviu Rebreanu Str., 310414, Arad, \\ Romania \\ 2Department of Urology, Arad County Emergency Hospital, 86 Liviu Rebreanu Str., 310414, Arad, Romania \\ ${ }^{3}$ Vasile Goldis Western University of Arad, Department of Experimental and Applied Biology, Institute of Life Sciences, 86 L.iviu \\ Rebreanu Str., 310414, Arad, Romania \\ ${ }^{4}$ Vasile Goldis Western University of Arad, Faculty of Medicine, Department of Surgery, 86 L.iviu Rebreanu Str., 310414, Arad, \\ Romania \\ ${ }^{5}$ Vasile Goldis Western University of Arad, Faculty of Medicine, Department of Obstetrics and Gynecology, 86 Liviu Rebreanu \\ Str., 310414, Arad, Romania \\ ${ }^{6}$ Sf. Pantelimon Emergency Clinical Hospital, 340-342 Pantelimon Road, 021659,Bucharest, Romania \\ ${ }^{7}$ Carol Davila University of Medicine and Pharmacy, 37 Dionisie Lupu Str., 020021, Bucharest, Romania \\ ${ }^{8}$ Elias Emergency Hospital, 17 Marasesti Str., 011461, Bucharest, Romania
}

\begin{abstract}
Male infertility is a common and complex problem affecting 1 out of 20 men. Despite extensive research in this area, in many cases, the underlying causes are unknown. Epigenetic changes control a series of processes within the body, including male fertility. Classification of infertile men using a more detailed analysis of DNA methylation patterns could reveal a new level of low rates of fertilization, implantation, or pregnancy. In this context, it seemed to us to use the techniques available to evaluate the degree of global methylation of DNA in infertile patients who have modified sperm counts, but also those who apparently do not have a clear cause of infertility. For this we used the Quest 5mC-Zymoresaerch-ELISA kit that can detect within about 5 hours the global level of genome methylation. Claims on which common illnesses have an epigenetic base are still open to speculation, but if true, it can imprint a new direction in medicine. Our data, although from a pilotstudy, are consistent with those in the literature. A recent study has shown that DNA methylation levels were significantly higher in oligoasthenoteratozoospermia patients than in the control group and the increase in global DNA methylation and histone retention in men with oligoasthenoteratozoospermia.
\end{abstract}

Keywords: male infertility, epigenetic markers, DNA methylation (5mC)

The World Health Organization (WHO) and the American Society for Reproductive Medicine (ASRM) define infertility as the impossibility of a couple to conceive a child after at least 12 months of unprotected sex [1]. According to WHO estimates, 60-80 million couples from all over the world are currently suffering from infertility [2]. Approximately $10 \%$ of couples in the United States are defined as infertile because of the inability to conceive according to the National Center for Health Statistics, infertility in women increased from 4.56 million in 1982 to 7.26 million in 2002, then decreased slightly to 6.71 million in 2006-2010 [3]. If feminine causes have benefited from much more intense and prolonged studies, and multiple causes have been identified from congenital malformations [4], ovulatory disorders [5-7], polycystic ovary syndrome [8,9], thrombophilia [10-12], malignant pathology [13,14], endocrine disorders, the causes of male infertility still remain unclear in high percentage and with multiple correlations with pathologies that can lead to erectile dysfunction of the cardiovascular cause [15].

Male infertility is a common and complex problem affecting 1 out of 20 men $[16,17]$. Despite extensive research in this area, in many cases, the underlying causes are unknown. Epigenetic factors play an important role in male infertility. Epigenetic changes control a series of processes within the body, including male fertility. Many recent studies have identified epigenetic profiles modified in semen from men with oligozoospermia and oligoasthenoteratozoospermia.
In primordial cells (mitosis), methylation of DNA occurs to establish specific paternal fingerprints. Phosphorylation (in the meiotic cell) occurs to aid both recombination and $X Y$ body formation. Ubiquitilation, sumorization and incorporation of the H2AZ and $\mathrm{H} 3.3$ variants are all involved in $X Y$ body formation. Hyperacetylation occurs during spermogenesis to help change Histone-Protamine. Spermatocytogenesis may also result in a chromosomal non-disjunction during its meiosis I and II along with double strand breaks, abnormal histone alterations and alterations in the expression of mRNA and other non-coding RNAs. DNA fragmentation is the consequence of apoptosis after double strand breakage or abnormal protamination during spermiogenesis [18].

\section{Hypotheses}

Claims on which common illnesses have an epigenetic base are still open to speculation, but if true, it can imprint a new direction in medicine. Knowing the genetic and epigenetic changes of germ cells is necessary for the production of functional gametes and for overcoming infertility. Classification of infertile men using a more detailed analysis of DNA methylation patterns could reveal a new explanation for levels of low rates of fertilization, implantation, or pregnancy. Epidemiological studies provide an important window in understanding the role of environmental interactions with the genome in triggering disease and modulating those interactions to improve human health. 


\section{Experimental part}

\section{Material and method}

In this context we used the techniques available to evaluate the degree of global methylation of DNA in infertile patients who have modified sperm counts, but also those who apparently do not have a clear cause of infertility. For this we used the Quest 5mC-Zymoresaerch-ELISA kit that can detect within about $5 \mathrm{~h}$ the global level of genome methylation.

The manufacturer's specifications were followed for the evaluation of the overall methylation degree. ELISA-type analysis was performed from 200ng DNA for each sample in duplicate. Additionally, each analysis was run in parallel with 8 internal controls. Measurements were made at $450 \mathrm{~nm}$ (gross values). In order to protect patients' personal data, their names have been truncated.
The mean values, analysis and calculation of the percentage of methylation are shown below. These values were also compared with the standard curve obtained from the test kit control samples (table 1, fig.1).

Reactivity of the samples can be seen in the images below (see table layout above). As a color reaction, you can see the color difference (yellow) before the measurement at 450nm (fig.2).

In order to have additional control, we used 200ng of control DNA from the Y-Promega Microdeletion kit with which the PCR reactions.

The red cells are azoospermia patients presenting the microdeletions on the $Y$ chromosome. Blue patients are presented with oligosospermia (fig.3).

\begin{tabular}{|c|c|c|c|c|}
\hline \multicolumn{5}{|c|}{ Standard curve C0-C5 } \\
\hline & & 5mc-nou & var quest & \\
\hline & $\begin{array}{l}\% 5 \mathrm{mC} \\
(\mathrm{x})\end{array}$ & $\ln (\% 5 \mathrm{mc})$ & $\ln (\% 5 \mathrm{mc}+1)$ & Absorbant: \\
\hline $\mathrm{NC}^{-}$ & 0 & & 0,000 & 0,242 \\
\hline $\mathrm{Cl}(\mathrm{M} 4)$ & 0,1 & $-2,303$ & 0,095 & $0,253^{3}$ \\
\hline $\mathrm{C} 2$ & 0,2 & $-1,609$ & 0,182 & 0,253 \\
\hline $\mathrm{C} 3$ & 0,5 & $-0,693$ & 0,405 & 0,302 \\
\hline $\mathrm{CH}^{-}$ & 1 & 0,000 & 0,693 & $0,370^{-3}$ \\
\hline $\mathrm{C} 5$ & 2 & 0,693 & 1,099 & 0,417 \\
\hline $\mathrm{C} 6$ & 5 & 1,609 & 1,792 & 0,796 \\
\hline $\mathrm{C}$ & & & & \\
\hline & & & & \\
\hline
\end{tabular}

Table 1

STANDARD CURVE AND HOW TO CALCULATE 5MC METHYLATION PROCENTAGE OF DNA

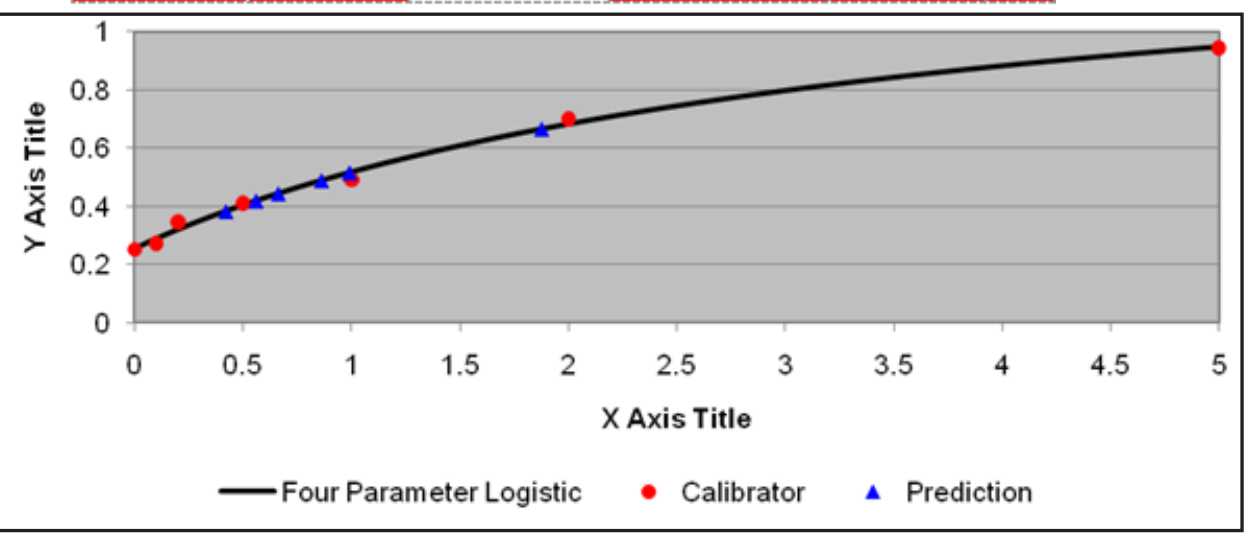

\begin{tabular}{|c|c|c|c|c|c|c|}
\hline Coeff. & Value & \pm Error & Measure & Value & X Axis Title & Y Axis Title \\
\hline $\mathrm{a}$ & 0.2537 & 0.0238 & $\mathrm{R}^{2}$ & 0.995 & 0 & 0.252 \\
\hline $\mathrm{b}$ & 0.9741 & $0.4586^{\circ}$ & $\mathrm{aR}^{\mathrm{z}^{-1}}$ & 0.987 & 0.1 & $0.272^{-}$ \\
\hline $\mathrm{c}$ & 3.7331 & $2.9129^{--}$ & $\mathrm{P}$ & $0.001^{1}$ & 0.2 & $0.346^{-}$ \\
\hline \multirow[t]{4}{*}{$\mathrm{d}$} & 1.4705 & $0.2495^{-}$ & $\mathrm{SE}^{-}$ & 0.026 & 0.5 & $0.41^{-}$ \\
\hline & & & $\mathrm{F}$ & $138.710^{-}$ & 1 & $0.49^{\circ}$ \\
\hline & & & & & 2 & $0.7^{-}$ \\
\hline & & & & & 5 & $0.945^{\circ}$ \\
\hline
\end{tabular}

Fig.1. Standard curve and how to calculate $5 \mathrm{mC}$ methylation procentage of

DNA samples from infertile patients under ELISA with the Quest$5 \mathrm{mC}$-ZymoResearch kit. 

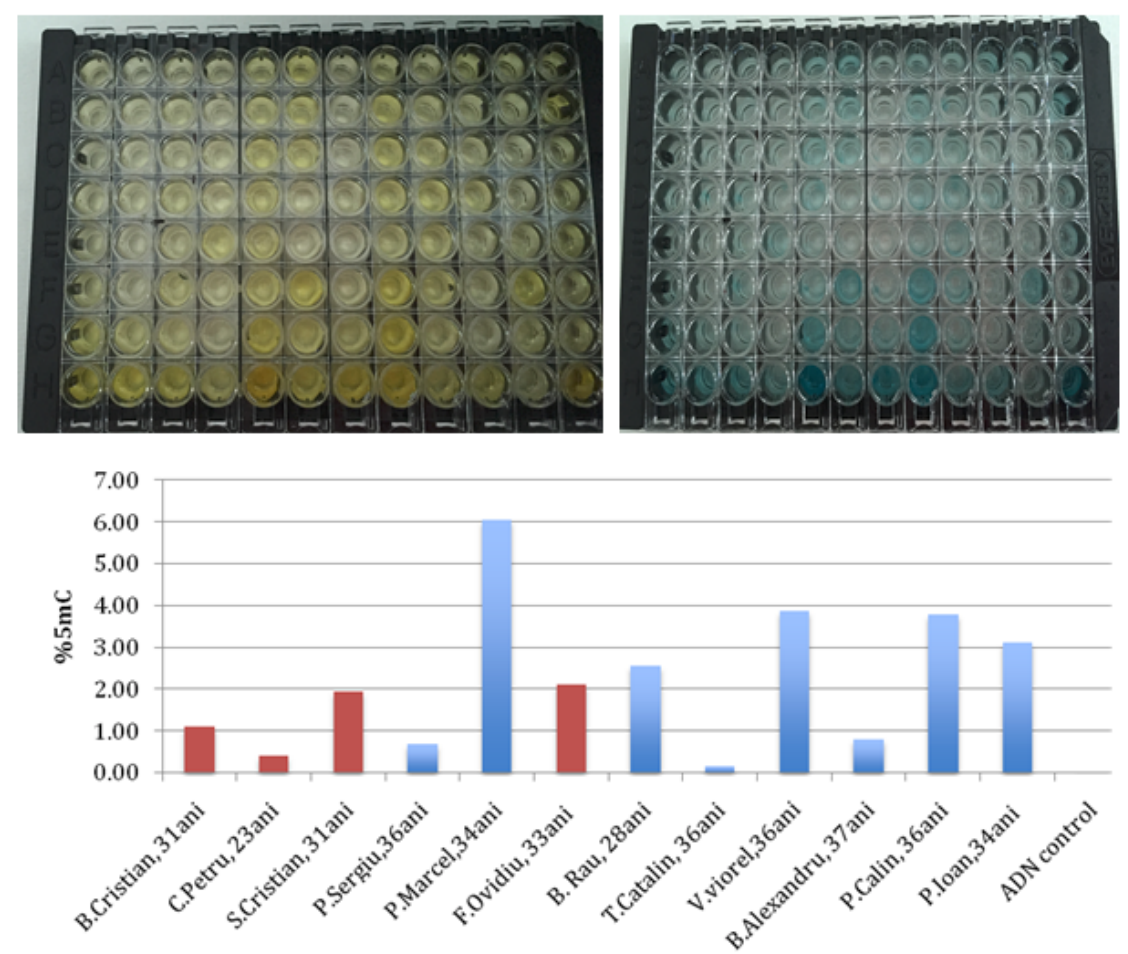

Fig.2 ELISA plates used to evaluate the degree of $5 \mathrm{mC}$ methylation in infertile patients. Yellow = enzymatic reaction. Blue = enough ADN methylated.
Fig. 3.Global $5 \mathrm{mClevel}(\%)$ for patients assessed. In red, there are azoospermia patients presenting the microdeletions on the Y chromosome. Blue patients are presented with oligosospermia
Recently, it has been discovered that 5-hydroxymethylcytosine modification ( $5 \mathrm{hmC}$ ) plays an important but poorly understood role in gene expression. Accumulation of 5-methylcytosine (5mc) in gene promoters is associated with gene inactivation, a process that subsequently triggers the binding of the methyl group to specific binding proteins, which then recruit histone deacetylation and chromatin remodeling complexes and other co-repressors [19].

To assess the overall degree of hydroxymethylation, the manufacturer's specifications were followed using the Zymoreasearch Queat 5hmC-ELISA kit. ELISA-type analysis was performed from 100ng DNA for each sample in duplicate. Additionally, each analysis was run in parallel with 8 internal controls. Measurements were made at
$450 \mathrm{~nm}$ (gross values). In order to protect patients' personal data, their names have been truncated.

The calculation method was performed according to kit specifications. Reactivity of samples can be seen in the images below (see above plate positioning). As a color reaction, you can see the color difference (yellow) before measuring at 450nm (fig.4).

To have additional control, we used 100ng of control DNA from the Y-Promega Microdeletion Kit with which the $P C R$ reactions were performed.

In red, there are azoospermia patients who presented the microdeletions on the $Y$ chromosome. In blue, patients with oligosospermia are present.

$5 \mathrm{hmC}$ levels in infertile patients are variable and in some cases could not be detected (fig.5).
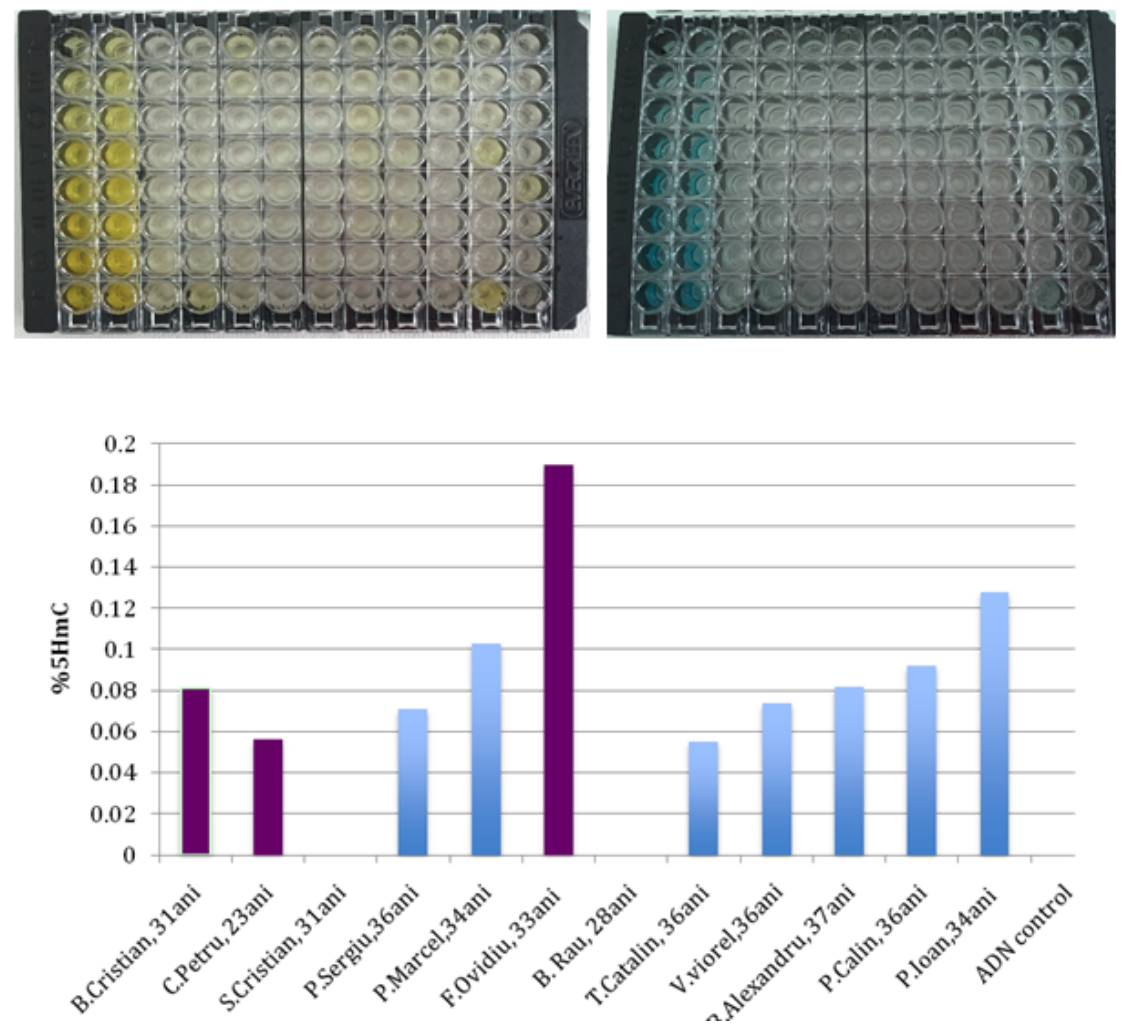

Fig. 4. ELISA plates used to assess the $5 \mathrm{hmC}$ methylation degree in infertile patients. Yellow $=$ enzymatic reaction. Blue $=$ hydroxymethylated $\mathrm{ADN}$
Fig. 5. The level of $5 \mathrm{mC}$ global (\%) for each evaluated patient 
These data are informative about the degree of demyelination of the genome. Additional studies are needed to highlight the role of this new epigenetic biomarker in infertility and not only.

\section{Results and discussions}

In addition to genetic screenings and proteome analyzes, the study of epigenetics and post-translational changes (PTM) is a supportive and promising research field for the study of idiopathic infertility. These changes in epigenetics and PTM are caused by genetic or environmental factors and can be used as biomarkers for male infertility.

Epigenetics was defined as the study of gene function modifications that are hereditary mitotic and / or meiotic and not involving a DNA sequence change [20]. The most important epigenetic events in sperm cells are: (i) histamine replacement with protamine; (ii) retaining certain histones in the key regions of the genome; and (iii) hypomethylation of certain DNA regions. In addition, noncoding RNA can also be seen as an essential epigenetic modifier. It has been suggested that epigenetic disorder may be implicated in the etiology of male idiopathic infertility [21].

However, causal links between different epigenetic profiles and infertility remain unclear. The use of epigenetics as an indication or cause of male infertility is barely beginning to be thoroughly explored and is currently not well understood. Jenkins et al. (2017) [22] analyzed the potential clinical applications of promising sperm epigenetics for the study of idiopathic infertility. They concluded that there are emerging data suggesting that the predictive power of methylation signals, in particular DNA, and RNA signals in spermatozoa that probably exceeded the traditional techniques of male infertility assessment. DNA methylation signatures remain remarkably stable during the spermatogenesis process, making it an attractive technique for assessing spermatogenic health by observing mature sperm (sperm cells are easy to collect compared to testicle biopsy). However, many further research is needed in this area.

Oligoasthenoteratozoospermia is the most common cause of male subfertility and affects approximately $30 \%$ of infertile men [23]. It is known that during spermatogenesis, some changes occur in chromatin, allowing the development of specific epigenetic profiles in spermatozoa. Recent evidence has suggested that some epigenetic changes in spermatozoa, such as DNA methylation, may play an importantrole in the development of male fertility $[24,25]$. Significant changes in sperm counts in $22 \%$ of infertile men have led to abortion. It supports the idea that epigenetic disorders can explain the high incidence of abortion in humans [26].

DNA methylation is a DNA-methyltransferase-catalyzed epithelial modification (DNMTs) that can effectively promote gene expression. DMNTs are classified into three types of enzymes in mammals (DNMT1, DNMT2 and DNMT3) [27]. DNMT1 is the most common enzyme and plays a key role in the methylation of hemimetized $\mathrm{CpG}$ dinucleotides in the mammalian genome; is considered to be the major target of methyltransferase during cell division, while DNMT3 function is de novo methylation [28]. Some studies have shown that methylation was significantly reduced in all CpGs in oligoasthenoteratozoospermic men, suggesting a association of abnormal DNA genomic printing with oligoasthenoteratozoospermia $[29,30]$.

Higher levels of sperm nuclear organization occur shortly after fertilization and are important for initiating and regulating paternal gene activity in the early embryo [31]. Inappropriate metylization is present in more than $20 \%$ of low sperm counts, low sperm motility and abnormal sperm morphology. Fragmentation of sperm DNA has been shown to increase with the overall increase in metylization in infertile men [32]. Similarly, a correlation between the global methylation level and the chromatin lesion status detected by the blue aniline test (AB) was observed in samples from oligoasthenoteratozoospermia patients [33], although previous data showed an insignificantrelationship between total methylation quality and DNA fragmentation [34].

Therefore, the literature contains insufficient evidence of transcriptional relationships of DNMTs, such as DNMT1, DN-MT3A and DNMT3B, with global sperm DNA methylation and chromatin integrity.

A recent study showed that DNA methylation levels were significantly higher in patients with oligoasthenoteratozoospermia than in the control group [35]. Yu et al., 2015 showed that DNA methylation levels were lower in selected sperm than in unprocessed sperm, which is similar to the results of Tahereh's 2018 study on the increase in global methylation DNA and histone retention in men with oligoasthenoteratozoospermia. Similarly, Barziedh et al., 2013 [36] showed that the amount of 5-mC as a percentage of total cytosine was significantly lower in highgrade sperm, which was also confirmed by the results of immunohistochemistry.

Higher overall methylation levels in patients with oligoasthenoteratozoospermia were associated with lower levels of concentration, progressive motility and normal morphology. In contrast, Olszewska et al., 2017 [33] examined global methylation levels by estimating 5-mC levels in spermatozoa with chromosomal abnormalities and in normal sperm and showed that levels of DNA methylation were similar in both groups and that there are no correlations between sperm methylation, morphology and progressive motility.

Increasing global methylation levels of patients has led to increased dysfunction of spermatozoa / dysfunction of DNA. Aoki and colleagues [32,37] evaluated the relationship between chromatid / DNA fragmentation in infertile men and total spermatozoid DNA methylation and found a significant association with the low quality of semen and DNA integrity. Similarly, a correlation analysis between global methylation and chromatin levels of protamine showed a positive association in the oligoasthenoteratozoospermia group, while a previous study showed a weak relationship of global methylation patterns with sperm quality and DNA fragmentation. However, the tendency to undergo apoptosis is related to the stage of global methylation of sperm DNA. In addition, extensive chromatin denaturation occurs in poor quality sperm. Such a process probably allows the opening of the chromatin structure, allowing the anti-5-mC antibody to access the methylation sites [38].

Some infertility and hormonal factors have also been involved in other pathologies $[39,40]$.

\section{Conclusions}

Male infertility is a relatively frequent and complex problem.

DNA methylation levels were significantly higher in oligoasthenoteratozoospermia patients than in the control group and the increase in global DNA methylation and histone retention in men with oligoasthenoteratozoospermia.

A correlation analysis between global methylation and chromatin levels of protamine showed a positive 
association in the oligoasthenoteratozoospermia group, while a previous study showed a weak relationship of global methylation patterns with sperm quality and DNA fragmentation.

Our data are informative about the degree of demyelination of the genome. Additional studies are needed to highlight the role of this new epigenetic biomarker in infertility and not only.

\section{References}

1. ZEGERS-HOCHSCHILD F, ADAMSIN GD, DE MOUZON J, ISHIHARA O, MANSOUR R, NYGREN K et al, Fertil Steril, 92, 2009, p. 1520.

2. CALVERTON, Maryland, USA: DHS Comparative Rep. No 9.

3. STEPHEN EH, CHANDRA A, Fertil Steril, 86, 2006, p. 516.

4. SOCEA, B., CONSTANTIN, V., CARAP, A., MOCULESCU, C., PADEANU, N., POPA, F., Chirurgia (Bucharest), 107, no. 2, 2012, p. 659.

5. DIMITRIU, M., SOCEA, B., IONESCU, C.A., PLES, L., GHEORGHIU, D.C., CONSTANTIN, V.D., CIRSTOVEANU, C.G., BACALBASA, N., FURAU, C.G., DAVITOIU, D.V., GHEORGHIU, N., Rev. Chim. (Bucharest), 70, no.4, 2019, p. 1248.

6. DIMITRIU, M., SOCEA, B., PLES, L., GHEORGHIU, D.C., GHEORGHIU, N., NEACSU, A., CIRSTOVEANU, C.G., BACALBASA, N., FURAU, C.G., FURAU, G.O., BANACU, M., IONESCU, C.A., Rev. Chim. (Bucharest), 70, no. 3, 2019, p. 1058

7. DIMITRIU, M.C.T., IONESCU, C.A., GHEORGHIU, D.C., SOCEA, L.I., BRATU, O.G., CONSTANTIN, V.D., PLES, L., NEACSU, A., BOBIC, S., SOCEA, B., Rev. Chim. (Bucharest), 69, no. 9, 2018, p. 2391.

8. IONESCU AC, POPESCU I, BANACU M, MATEI A, BOHILTEA R, DIMITRIU M, 5TH ROMANIAN CONGRESS OF THE ROMANIAN SOCIETY OF ULTRASOUND IN OBSTETRICS AND GYNECOLOGY, Proceedings, Filodiritto Editore, 2017, p. 194.

9. NEACSU, A., CALIN, A., BRAILA, A.D., NAVOLAN, D., DIMITRIU, M., STANICA, C.D., IOAN, R., IONESCU, C., Rev. Chim. (Bucharest), 69, no. 7, 2018, p. 1796.

10. MITRANOVICI, M.I., PUSCASIU, L., CRAINA, M., et al. Rev. Chim. (Bucharest), 68, no. 12, 2017, p. 2970.

11. SAFTA AN, CONSTANTIN VD, SOCEA LI, SOCEA B, Farmacia, 60, no. 1,2012 , p. 127.

12. LASLO CL, PANTEA STOIAN A, SOCEA B, PADURARU DN, BODEAN 0 , SOCEA LI, NEAGU TP, STANESCU AMA, MARCU D, DIACONU CC, J Mind Med Sci, 5, no. 2, 2018, p. 195.

13. TATARU AL, FURAU G, AFILON J et al, J ournal of Clinical Medicine, 8, no. 1, 2019, p. E96.

14. DRAGHICI T, NEGREANU L, BRATU OG, PANTEA STOIAN A, SOCEA $B$, NEAGU TP, STANESCU AMA, MANUC D, DIACONU CC, Rom Biotehnol Lett, 23, no. 6, 2018, p. 1.

15. UIVAROSAN D, ABDEL-DAIM MM, ENDRES L, et al, Farmacia, 66, no. 5,2018 , p. 826.
16. DIACONU CC, MANEA M, MARCU DR, SOCEA B, SPINU AD, BRATU OG, Acta cardiologica, 2019, p. 1-7, doi: 10.1080/00015385.2019.1590498. 17. SILEA C, CUCU IA, ZARNESCU O, PANTEA STOIAN A, MOTOFEI IG, BRATU OG, PIRCALABIORU GG, CHIFIRIUC MC, Rom Biotehnol Lett, 24, no. 1, 2019, p. 82.

18. DADA R, KUMAR M, JESUDASAN R, FERNANDEZ J L, GOSALVEZ J , AGARWAL A, J Assist Reprod Genet, 29, no. 3, 2012, p. 213.

19. DONG-QIAO S, IFTIKHAR A, JUN T, WEI-CAI Y, Front. Genet., 8, 2017, p. 100

20. DUPONT C, ARMANT DR, BRENNER CA, Semin. Reprod. Med., 27, no. 5,2009 , p. 351.

21. CARRELL DT, Fertil. Steril., 97, no. 2, 2012, p. 267. doi:10.1016/ j.fertnstert.2011.12.036.

22. JENKINS TG, ASTON KI, J AMES ER, CARRELL DT, Syst. Biol. Reprod. Med., 63, no. 2, 2017, p. 69.

23. CAVALLINI G, Asian J Androl, 8, no. 2, 2006, p. 143.

24. KOMIYA A, KATO T, KAWAUCHI Y, WATANABE A, FUSE H, Scientific World J ournal, 2014; 2014: 868303.

25. CUI X, JING X, WU X, YAN M, LI Q, SHEN Y, et al, Exp Ther Med, 12, no. 4, 2016, p. 1973.

26. CAMPRUBI C, PLADEVALL M, GROSSMANN M, GARRIDO N, PONS MC, BLANCO J, Epigenetics, 7, no. 10, 2012, p. 1115.

27. YANAGISAWA Y, ITO E, YUASA Y, MARUYAMA K, Biochim Biophys Acta, 1577, 2002, p. 457

28. KATO Y, NOZAKI M, PLoS One, 7, 2012, e43658.

29. CORTESSIS VK, THOMAS DC, LEVINE AJ, BRETON CV, MARCK TM, SIEGMUND KD, et al, Hum Genet, 131, 2012, p. 1565.

30. OWEN CM, SEGARS JH JR, Semin Reprod Med, 27, 2009, p. 417.

31. LATHAM KE, SCHULTZ RM, Front Biosci, 6, 2001, p. D748.

32. AOKI VW, EMERY BR, CARRELL DT, Fertil Steril, 86, 2006, p. 1541. 33. OLSZEWSKA M, BARCISZEWSKA MZ, FRACZEK M, HULEYUK $N$, CHERNYKH VB, ZASTAVNA D, et al, Asian J Androl, 19, 2017, p. 117. 34. BENCHAIB M, BRAUN V, RESSNIKOF D, LORNAGE J, DURAND P, NIVELEAU A, et al, Hum Reprod, 20, 2005, p. 768.

35. TAHEREH R, EHSAN FY, FARZANEH F, MOHAMMAD RM, ALI MOHAMMAD M, ALI REZA T, Clin Exp Reprod Med, 45, no. 1, 2018, p. 17.

36. BARZIDEH J, SCOTT RJ, AITKEN RJ, Andrologia, 45, 2013, p. 424. 37. AOKI VW, EMERY BR, CARRELL DT, J Androl, 27, 2006, p. 890.

38. MARQUES C] , JOAO PINHO M, CARVALHO F, BIECHE I, BARROS A, SOUSA M, Epigenetics, 6, 2011, p. 1354.

39. SOCEA, B., SOCEA, L.I., BRATU, O.G., MASTALIER, B., DIMITRIU, M., CARAP, A., CONSTANTIN, V.D., Mat. Plast., 55, no. 1, 2018, p. 79. 40. SOCEA, B., CARAP, A., BRATU, O.G., DIACONU, C,C, DIMITRIU, M., SOCEA, L.I, BOBIC, S., CONSTANTIN, V.D., Mat. Plast., 55, no. 2, 2018, p. 146.

$\overline{\text { Manuscript received:22.12.2018 }}$ 